UDK 339.727.2(497.7)

Preliminary paper

Prethodno priopćenje

\title{
THE ROLE OF REMITTANCES IN FINANCIAL CRISIS: EMPIRICAL EVIDENCE FROM MACEDONIA
}

\begin{abstract}
The recent global financial crisis has heated the debate among economists on the role of migrant workers' remittances in times of financial crisis: Are they a shock absorber or a shock transmitter? The objective of this paper is to find out whether the remittances sent to Macedonia have a stabilizing or destabilizing effect. By specifying a vector error correction (VEC) model, we find evidence that real remittances have a destabilizing effect on the output both of the home country (Macedonia) and the host country (Germany). Consequently, they could not cushion large fluctuations in Macedonian output in stage of economic downturn.
\end{abstract}

Key words: remittances, migration, cyclicality, financial crisis, vector error correction model (VEC)

JEL classifications codes: C22, F29, J61, O11, O24

\section{INTRODUCTION}

Although at the beginning of the recent global financial and economic crisis, which started in summer 2007 when the first problems in US securities markets based on real estate loans occurred, it was thought that the current crisis will not affect Macedonia because it had no exposures to the US real estate market and because of the completely different structure of the Macedonian real estate market. Macedonia, like all other countries in Eastern and South Eastern Europe countries, has also been drawn in the severest crisis since the chronic days of the Great Depression via the trade and the capital flow channel. The global financial crisis started affecting the economy in the fourth quarter of 2008, led by a decline in the output of the metal and textile sectors. The macroeconomic situation deteriorated further in 2009 as industrial production contracted by 7.7 per cent compared with 2008, while foreign trade dropped sharply and foreign direct investment (FDI) declined by more than 66 per cent (National Bank of the Republic of Macedonia, 2011).

Unlike the FDI inflows, the migrant workers' remittances, which accounted for 4,5\% of its GDP in $2009^{2}$, have decreased by only 2\% in 2009 compared with 2008 and in 2010 they reached a record level of 414 million US dollars (World Bank, 2011) which represents an increase of 3\% compared with 2009. This is line with the data on remittances in other developing countries, which are estimated to reach the record level of 325 billion dollars in 2010, up from 307 billion dollars in 2009 (World Bank, 2011).

\footnotetext{
${ }^{1}$ University “Ss. Cyril and Methodius”, Faculty of Economics-Skopje, Krste Misirkov bb, 1000 Skopje, Macedonia, e-mail: vesna@eccf.ukim.edu.mk

${ }^{2}$ Macedonia is among the leading 30 migration countries with 21.9 percent stock of emigrants as a percentage of population (World Bank, 2011).
} 
Figure 1: Quarterly remittance inflows to Macedonia in the period 2007-2010 in millions of US dollars

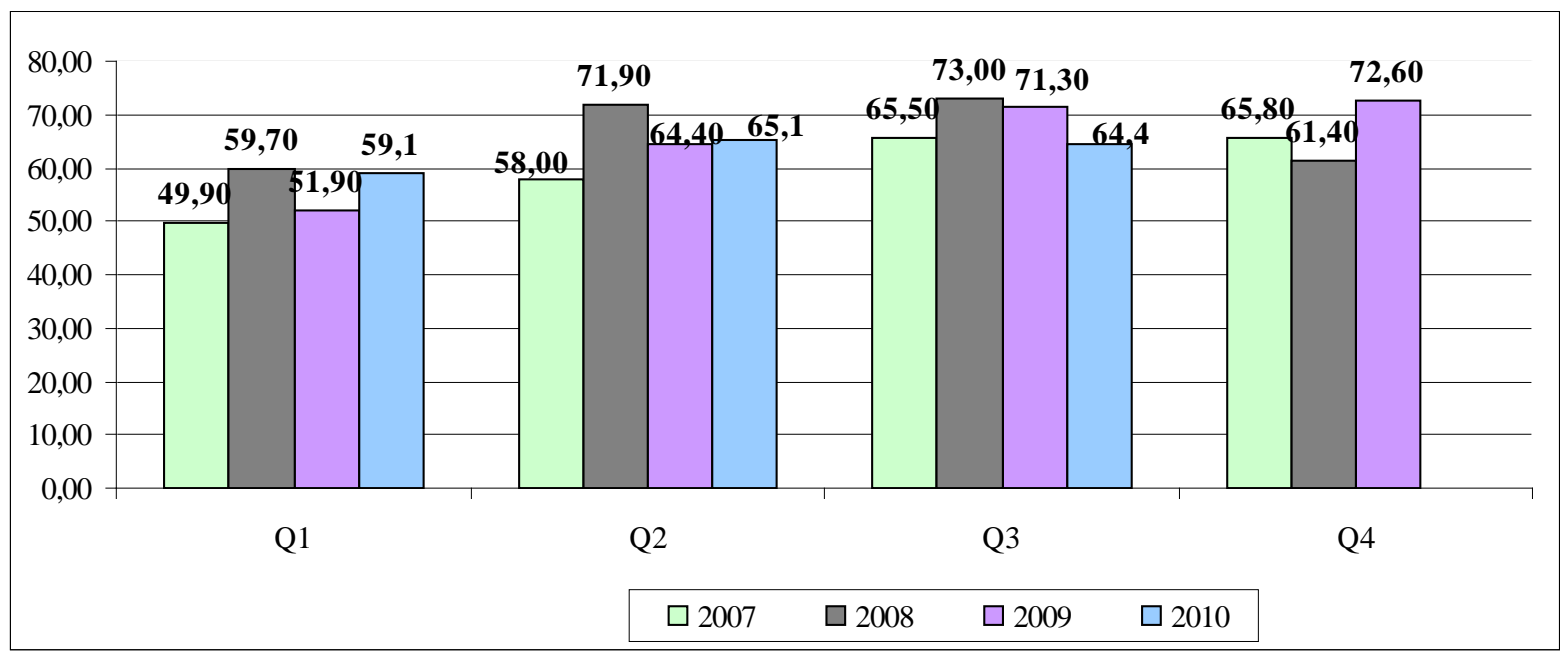

Source: National Bank of the Republic of Macedonia, Statistics, http://www.nbrm.mk/default en.asp?ItemID=16C5679A8986CE4391D1F76413410999, Assessed on 10

The rising trade deficit, on one hand and the sharp decline of FDI, on the other hand have pushed up the current account deficit. Not only the size of the current account deficit, but also the speed of its deterioration are of great concern. Indicators of external vulnerability, such as international reserve cover of imports, or of short-term foreign debt, have also worsened in 2009. Macedonia's international reserves declined sharply in the first two quarters of 2009 (see Figure 2), with exports decreasing faster than imports. The National Bank of the Republic of Macedonia responded to the sharp reserve outflows by tightening bank liquidity and reserve requirements and raising its policy rate from 7 percent to 9 percent. As a result of that policy, in the third quarter of 2009 the situation had stabilized and reserve losses from earlier in the year had been recouped. As a result of that, at the end of 2009 Macedonia recorded an increase of 7 percent in the foreign exchange reserves compared with 2008 (National Bank of the Republic of Macedonia, 2011) .

Figure 2: Quarterly gross foreign exchange reserves in 2008 and 2009 in millions of US dollars

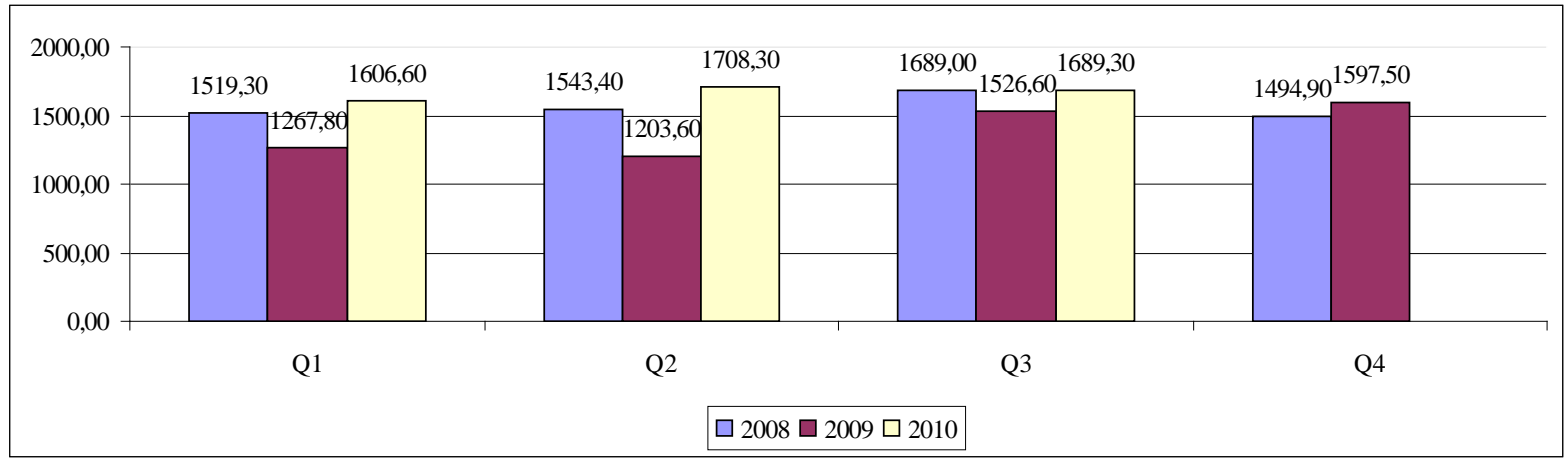

Source: National Bank of the Republic of Macedonia, Statistics,

http://www.nbrm.mk/default-en.asp?ItemID=16C5679A8986CE4391D1F76413410999, Assessed on $10^{\text {th }}$ January 2011. 
Given the persistent problems in the Macedonia's trade balance and balance of payment, on one hand and the important role that migrant remittances have been played in financing between 80-90 percent of the Macedonian trade deficit, it is of utmost importance to find out whether the remittances sent to Macedonia by Macedonian migrants working in Germany have a stabilizing or destabilizing effect on the output of the home country (Macedonia) and of the host country (Germany). We have chosen Germany due to the fact that Germany has been among the top ten destination countries for immigrants from Macedonia and the dominant EU receiving country of immigrants from Macedonia (in the period 2000-2009 the share of Macedonian immigrants working in Germany in the total number of Macedonian immigrants averaged 15 per cent), and as such it constitutes the largest source country of remittances to Macedonia.

\section{STYLIZED FACTS}

The trend of migrant workers' remittance inflows to Macedonia is broadly in line with the trend observed in global remittance flows and the trend of remittance inflows to developing countries.

Migrant workers remittances ${ }^{3}$ inflows to Macedonia have been constantly growing in the period 2000-2010 (Figure 3) averaging 246.18 million US dollars. It should be noted that these figures are official figures provided by the World Bank statistics division. However, the World Bank suggests that remittances sent through informal channels could add at least $50 \%$ to the official estimate (World Bank, 2006)

The annual rate of growth of workers' remittances to Macedonia in the period 20002010 have averaged 19.5 percent. In the same period the inward migrant workers remittances per capita also increased significantly at an average rate of 19.31 percent (Figure 4).

Figure 3: Inward migrant workers remittances in Macedonia in millions of US dollars, 20002010

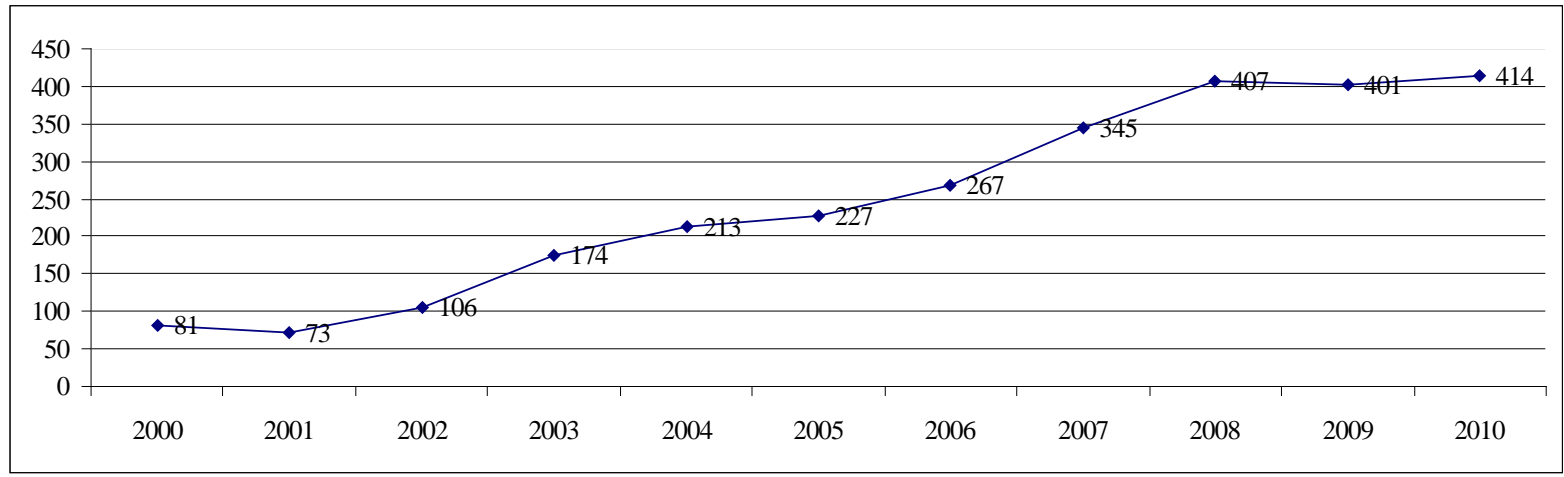

Source: National Bank of the Republic of Macedonia, Statistics, http://www.nbrm.mk/defaulten.asp?ItemID=16C5679A8986CE4391D1F76413410999, Assessed on 10 ${ }^{\text {th }}$ January 2011.

\footnotetext{
${ }^{3}$ The World Bank definition of remittances includes workers remittances, compensation of employees and migrant transfers. In case of Macedonia the migrant transfers are included in the cash exchange.
} 
Figure 4: Per capita inward migrant workers remittances in Macedonia, 2000-2010

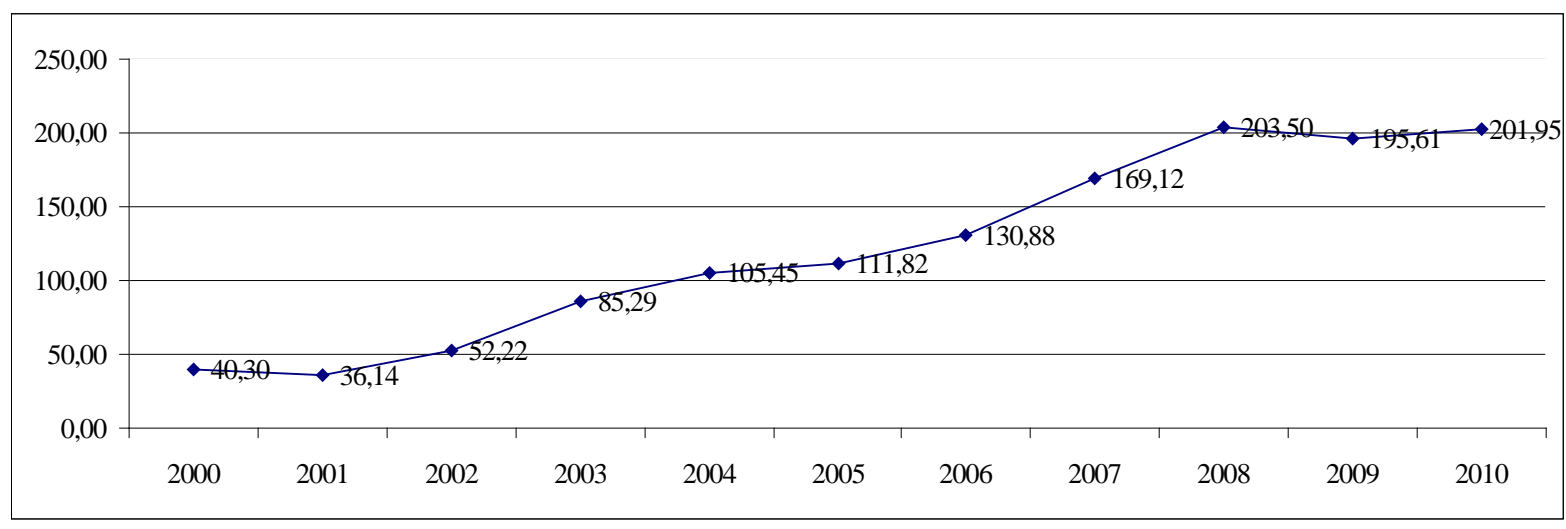

Source: National Bank of the Republic of Macedonia, Statistics, http://www.nbrm.mk/defaulten.asp?ItemID=16C5679A8986CE4391D1F76413410999, Assessed on $10^{\text {th }}$ January 2011.

Since 2002 workers' remittances have become the largest source of external financing for the Macedonian economy, by far exceeding other capital inflows, such as foreign direct investments (FDI), official development assistance and portfolio investment. Adding to the importance of remittances at a macro level, remittances are a significant source of external funding for many households, particularly in times of economic hardships.

In the economic literature as well as in the empirical research it is widely believed that workers' remittances are motivated by altruism (Rapoport and Docquier, 2005) and as such are expected to move countercyclical to the GDP in the recipient country. Ratha (2003) also corroborates the point that migrants may also increase remittances in times of economic hardship. However, since the decision to remit money is influenced not only by altruism, but by a number of determinants, it is conceivable that remittances may be procyclical or even acyclical with the GDP in some of the recipient countries (Sayan, 2006).

When they are countercyclical with the business cycle of the recipient country, they serve as a macroeconomic stabilizer. On the other hand when they are procyclical they may act as a destabilizing effect by amplifying cyclical fluctuations in GDP (Sayan and TekinKoru, 2007).

It is therefore important to find out if remittance inflows from Germany to Macedonia are countercyclycal, procyclical or even acyclical to the movements of Macedonian as well as German GDP over the different stages of the business cycle and to establish the main determinants of remittance inflows from Germany as the largest source country of remittances to Macedonia.

\section{DATA, METHODOLOGY AND RESULTS}

In order to investigate whether the workers' remittances sent to Macedonia by workers from Macedonia working in Germany are countercyclical or procyclical with macroeconomic conditions in the home country (Macedonia) and host country (Germany), we will estimate a vector error correction (VEC) model for Macedonia using quarterly data covering the period 2000-2009. The model is estimated and tested using the econometric software package EViews 6. 
We decided to use the VEC model because: 1 . most of the macroeconomic variables are endogenous, suggesting a multi-equation estimation; 2. many of the time series of the variables are non-stationary in their levels, but are in their differences and 3 . there is a cointegrated relationship among the variables, suggesting the inclusion of the cointegrated relationship as an additional regressor. Our initial impressions are gained from looking at plots of the time series of the variables.

The dependent variable in our model is real migrant workers' remittances per capita sent by the Macedonian workers working in Germany to their families in Macedonia. Data on migrant workers' remittances to Macedonia in millions of US dollars are obtained from the National Bank of the Republic of Macedonia. We convert the quarterly remittances figures in nominal US Dollar terms into quarterly real values by dividing them by the GDP deflator. In order to determine the amount of worker remittances coming from Germany, we have calculated the share of workers from Macedonia working in Germany in the total number of migrant workers from Macedonia in the world as in Sayan and Tekin-Koru (2007) and after that we have used these weights for calculation the portion of remittances coming from Germany.

The selection of the explanatory variables is based on the previous empirical studies on the macroeconomic determinants of remittances listed in Table 1. These studies usually focus on the number of workers, wage rates and economic situation in host country, economic situation in country of origin, the exchange rates and relative interest rate between the sending and receiving country and political risk and facilities to transfer funds (i.e. institutions).

Table 1 gives a summary of the major empirical papers on the macroeconomic determinants of remittances. It is clear from this table that stock of migrants and the economic situation in the home and host country seem to be the most important factors for increased remittances.

In our model we use the following explanatory variables: the real gross domestic product (GDP) per capita in Macedonia as a proxy for the income level in the home country, the real gross national income (GNI) per capita in Germany as a proxy for the income level in the host country, the labour market situation in the home country proxied by the unemployment rate in Macedonia, the consumer price index (CPI) in Macedonia and the real effective exchange rate (REER) as proxies for macroeconomic stability in Macedonia and the interest rate difference (INTERESTDIF) between the short-term deposit interest rates in the home and host country (difference between the treasury bill rate in Macedonia and the treasury bill rate in Germany) as relative rate of return. 
Table 1: Macroeconomic determinants of remittances

\begin{tabular}{|c|c|c|c|c|c|c|c|c|c|}
\hline PAPER & 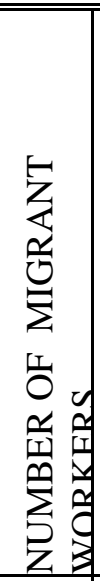 & 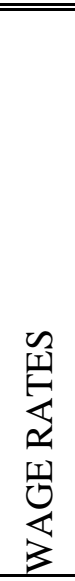 & 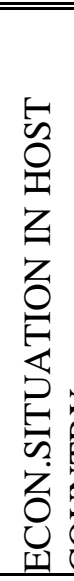 & 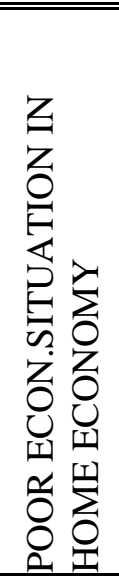 & 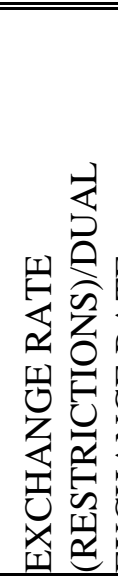 & 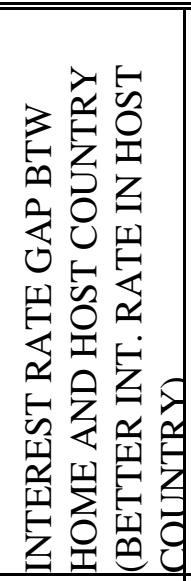 & 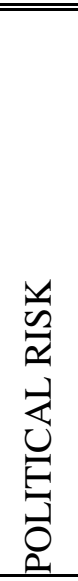 & 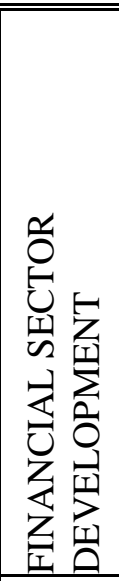 & 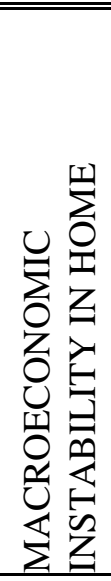 \\
\hline $\begin{array}{l}\text { Akkoyunlu and Kholodilin } \\
\text { (2006) }\end{array}$ & & & + & $\mathrm{x}$ & & & & & \\
\hline $\begin{array}{l}\text { Ayadas, Neyaptiand and } \\
\text { Metin-Ozcan (2006) }\end{array}$ & & & + & + & - & & - & & - \\
\hline Bouhga-Hegbe (2006) & & & & + & & & & & \\
\hline $\begin{array}{l}\text { Buch, Kuchulenzandle and } \\
\text { Manchec }(2002,2004)\end{array}$ & $\mathrm{x}$ & $\mathrm{x}$ & $\mathrm{x}$ & - & $\bar{x}$ & $\bar{x}$ & & $\mathrm{x}$ & $/-(1)$ \\
\hline $\begin{array}{lll}\text { Jovicic and Dragutinovic } \\
(2006)\end{array}$ & + & $\mathrm{x}$ & & - & & & & $\mathrm{x}$ & \\
\hline Elbadawi and Rocha (1992) & + & & + & & - & - & & & - \\
\hline Faini (1994) & & & & & $(2)$ & & & & \\
\hline Freund and Spatafora (2005) & + & & + & & - & & & $(3)$ & \\
\hline Gupta (2005) & (4) & + & + & + & $\mathrm{x}$ & $\mathrm{x}$ & $\mathrm{x}$ & & \\
\hline IMF (2005) & & & + & + & - & $\mathrm{x}$ & $\mathrm{x}$ & $\mathrm{x}$ & - \\
\hline Lianos (1997) & + & + & + & $\mathrm{x}$ & - & + & & & $(1)$ \\
\hline $\begin{array}{l}\text { Luethand and Ruiz-Arranz } \\
\text { (2006) }\end{array}$ & & & (5) & & & & & & + \\
\hline $\begin{array}{l}\text { Luethand and Ruiz-Arranz } \\
\text { (2007) }\end{array}$ & & + & + & + & - & & & & \\
\hline Russell (1986) & + & + & $*$ & $*$ & $*$ & $*$ & - & + & \\
\hline Sayan (2006) & & & $\mathrm{x}$ & - & & & & & \\
\hline Schiopu (2006) & & & + & + & & $\mathrm{x}$ & & & \\
\hline Schrooten (2005) & & + & + & + & & & & $\mathrm{x}$ & \\
\hline Schrooten (2006) & (4) & & + & & & & & + & \\
\hline
\end{tabular}

+: positive effect; -: negative effect; x: included in regression but not significant

Source: Hagen-Zanker, J. and Siegel, M., 2007, p. 23.

According to the previous empirical studies mentioned in Table 1, home country income may affect migrant workers remittances either positively or negatively, depending on the motives to remit money (altruism or investment considerations). The income of the host country can be a significant factor of workers remittances due to better employment opportunities and higher wages offered to the migrant workers in the host country. We have chosen GDP as a measure of the income level of Macedonia (home country) and GNI as a proxy for host country income (Germany) on the basis of the national income conventions that define gross national product (GNP) as GDP plus net factor income from abroad (NFI). Since NFI includes net remittance receipts, home country's GDP and host country's GNP series leave out remittances sent home by migrant workers in the host country in question 
(Sayan, 2004) Thus, GDP for Macedonia and GNI for Germany would be the more appropriate output measure to analyze the cyclical behaviour of real remittances sent home by migrant workers against the home and host country outputs. The quarterly data for GNI are obtained from the World Development Indicators 2010 of the World Bank and the quarterly data for GDP for Macedonia are obtained from the State Statistical Office and the National Bank of the Republic of Macedonia. Data on quarterly GDP deflator for Macedonia are obtained from Ministry of Finance of the Republic of Macedonia and data on GDP deflator for Germany are obtained from the World Development Indicators 2009 of the World Bank.

The higher unemployment rate in the home country can be expected to increase the incentives for migration which may consequently cause increase of remittances. While high unemployment may be a cause for migration, the household's community needs to have a certain level of development for investment by the household to be effective. Consequently it is possible fewer remittances are sent to developing countries (Hagen-Zanker and Siegel, 2007). The quarterly unemployment rates for Macedonia are obtained from the State Statistical Office of the Republic of Macedonia.

As far as causation between remittances receipts in home country and interest rate differential between the home and host country deposit interest rates is concerned, the directions may not be that clear-cut. While an increase in the interest rate differential would encourage migrant workers to channel their remittances to home country so as to earn interest income from the domestic banks, higher interest rate differential may also reflect higher macroeconomic instability and higher investment risks in the home country and as such could discourage migrant workers to invest their money in the domestic banks. The data on shortterm interest rates (treasury bill rates) for Germany are taken from the United Nations Economic Commission for Europe, and for Macedonia from the National Bank of the Republic of Macedonia.

The impact of inflation (proxied by consumer price index) on migrant workers remittances is also ambiguous. Higher inflation rates would cause remittance inflows to decline suggesting that inflation acts as a proxy for macroeconomic instability and risks and therefore discourages the inflow of remittances or higher inflation in the home country is found to encourage more remittances flows to compensate for the loss of purchasing power. The quarterly data on consumer price index in Macedonia are taken from the United Nations Economic Commission for Europe.

The sign of the real effective exchange rate (REER) coefficient, as an important determinant of remittances, is a priori not clear. If families target a certain consumption level in domestic currency, depreciation would result in a negative sign through falling remittances. But, if the consumption basket also contains a considerable share of imported goods, a depreciation of domestic currency would be associated with an increase in remittances so as the preserve the family members purchasing power in the home country. The quarterly data on REER in Macedonia are taken from the National Bank of the Republic of Macedonia.

We first test for the presence of unit roots in the macroeconomic time series using the augmented Dickey-Fuller test and find that all series are integrated of order one. To determine the appropriate lag length we start with 9 lags and subsequently eliminate lags with insignificant coefficients. The choice of model, that is whether to include an intercept or time trend, is based on the approach of Doldado et.al., (1990). Under this approach, one starts with the least restrictive of plausible models (the test equation includes both the trend and 
intercept) and then introduces restrictions until the null hypothesis of a unit root is rejected (if at all). As it can be seen from the results in Table 1, the null hypothesis of a unit root in the levels of data series is not rejected, therefore they are all a nonstationary (have unit roots). Next we proceed with testing for a second unit root, by testing for a unit root in the first differences of each if the series $(\nabla)$. The results show that null hypothesis of the unit rot test in $\nabla$ is not accepted, so we can conclude that all the series are integrated of first order I(1).

Table 2: Unit root test of the series

\begin{tabular}{||l|l|c|c|c|c|c||}
\hline & \multicolumn{3}{|c|}{ LEVEL } & \multicolumn{3}{c||}{ FIRST DIFFERENCE } \\
\hline & t-ADF & $\begin{array}{l}\text { model } \\
*\end{array}$ & lags & t-ADF & model & lags \\
\hline REMITPC & -2.969302 & 2 & 1 & -4.273018 & 2 & 0 \\
\hline RGDPPC & -2.154357 & 2 & 0 & -5.702564 & 2 & 0 \\
\hline RGNIPC & -0.582429 & 2 & 0 & -3.567557 & 3 & 0 \\
\hline REER & -1.281195 & 2 & 0 & -6.230331 & 2 & 0 \\
\hline CPIM & 0.907843 & 2 & 9 & -4.730682 & 3 & 0 \\
\hline UNRATE & -1.430606 & 2 & 0 & -5.823180 & 2 & 0 \\
\hline $\begin{array}{l}\text { INTERESTDI } \\
\text { F }\end{array}$ & -1.609364 & 2 & 0 & -4.472809 & 3 & 0 \\
\hline \hline
\end{tabular}

* Model 2 includes intercept in test equation, but no trend, model 3 does not include any of them.

A graph of the series is shown in Figure 6. The series clearly move in a similar way in time.

Figure 5: Graph of the series

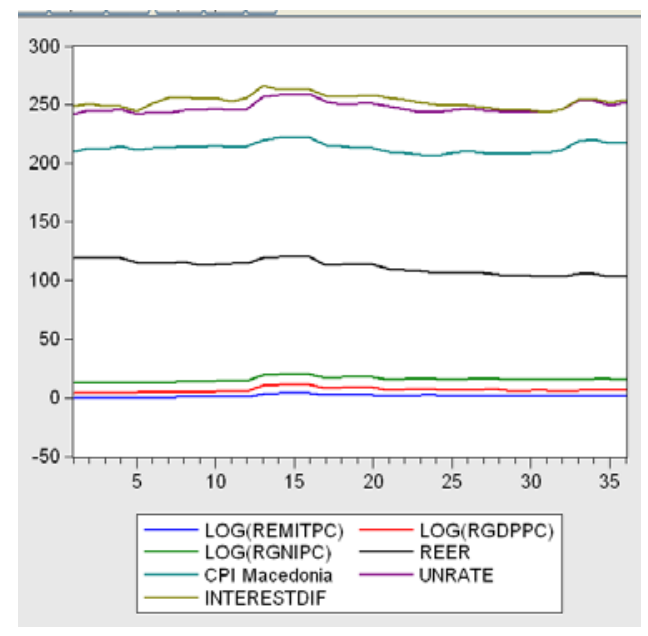

The next step is to test if there is a cointegration among the variables applying Johansen procedure. We use one lag to preserve sufficient degrees of freedom. Both the trace statistic and the maximum eigenvalue statistic confirm the existence of 2 cointegration relationships between log remittances per capita, log real GDP, log real GNI, real effective exchange rate, difference in interest rates, consumer price index in Macedonia and unemployment rate in Macedonia. 
The estimated OLS regression equation is the following:

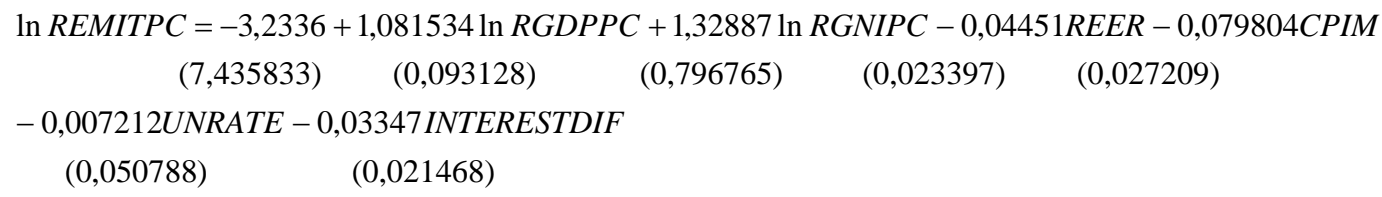

$(0,050788) \quad(0,021468)$

In order to see if this static relation is a long-run equilibrium relationship, and not just a spurious regression we have to test if the OLS residuals have a unit root, which implies that they are not stationary and the variables are not cointegrated, i.e. to implement the first phase of Engle-Granger procedure. The results of this test are given in Table 3.

Table 3: Dickey-Fuller t-test applied on the remittance residuals

\begin{tabular}{|c|c|c|c|c|}
\hline \multicolumn{5}{|c|}{ " Null Hypothesis: RESID02 has a unit root } \\
\hline \multicolumn{5}{|l|}{ Exogenous: Constant } \\
\hline \multicolumn{5}{|c|}{ Lag Length: 9 (Automatic based on SIC, MAXLAG=9) } \\
\hline & & & & \\
\hline & & & & \\
\hline & & & t-Statistic & Prob. $*$ \\
\hline \multicolumn{3}{|c|}{ Augmented Dickey-Fuller test statistic } & -4.625207 & 0.0011 \\
\hline \multirow[t]{4}{*}{ Test critical values: } & $1 \%$ level & & -3.711457 & \\
\hline & $5 \%$ level & & -2.981038 & \\
\hline & $10 \%$ level & & -2.629906 & \\
\hline & \multicolumn{4}{|c|}{ *MacKinnon (1996) one-sided p-values. } \\
\hline & & & & \\
\hline \multicolumn{5}{|c|}{ Augmented Dickey-Fuller Test Equation } \\
\hline \multicolumn{5}{|c|}{ Dependent Variable: D(RESID02) } \\
\hline \multicolumn{4}{|c|}{ Method: Least Squares } & \\
\hline \multicolumn{4}{|c|}{ Date: $07 / 10 / 09$ Time: $18: 03$} & \\
\hline \multicolumn{4}{|c|}{ Sample (adjusted): 1136} & \\
\hline \multicolumn{5}{|c|}{ Included observations: 26 after adjustments } \\
\hline & & & & \\
\hline & Coefficient & Std. Error & t-Statistic & Prob. \\
\hline RESID02(-1) & -2.252427 & 0.486989 & -4.625207 & 0.0003 \\
\hline D(RESID02(-1)) & 1.410548 & 0.395745 & 3.564282 & 0.0028 \\
\hline D(RESID02(-2)) & 0.930090 & 0.371914 & 2.500819 & 0.0245 \\
\hline D(RESID02(-3)) & 0.954700 & 0.313512 & 3.045182 & 0.0082 \\
\hline D(RESID02(-4)) & 1.076517 & 0.259401 & 4.150007 & 0.0009 \\
\hline D(RESID02(-5)) & 0.841375 & 0.228745 & 3.678226 & 0.0022 \\
\hline D(RESID02(-6)) & 0.603682 & 0.197654 & 3.054230 & 0.0080 \\
\hline D(RESID02(-7)) & 0.550644 & 0.150235 & 3.665208 & 0.0023 \\
\hline D(RESID02(-8)) & 0.353317 & 0.126901 & 2.784198 & 0.0139 \\
\hline D(RESID02(-9)) & 0.203369 & 0.092195 & 2.205854 & 0.0434 \\
\hline $\mathrm{C}$ & 0.024082 & 0.024396 & 0.987143 & 0.3392 \\
\hline
\end{tabular}




\begin{tabular}{|c|c|c|c|}
\hline R-squared & 0.862033 & Mean dependent var & -0.024584 \\
\hline Adjusted R-squared & 0.770055 & S.D. dependent var & 0.225080 \\
\hline S.E. of regression & 0.107932 & Akaike info criterion & -1.318526 \\
\hline Sum squared resid & 0.174739 & Schwarz criterion & -0.786254 \\
\hline Log likelihood & 28.14083 & Hannan-Quinn criter. & -1.165251 \\
\hline F-statistic & 9.372163 & Durbin-Watson stat & 2.059456 \\
\hline Prob(F-statistic) & 0.000086 & & \\
\hline & & & \\
\hline
\end{tabular}

We can conclude that the null hypothesis of no cointegration can be rejected even at level of significance of $2.5 \%$, meaning that the model (1) is a long-run equilibrium relationship.

Over the long run, remittance receipts increase as the Macedonian and German economy grows, and decline as the real effective exchange rate, unemployment rate, consumer price index in Macedonia and the difference between the short-term deposit interest rates in Macedonia and Germany increase.

The estimated short-run error correction model is given in the following figure:

Figure 6: The estimated error-correction model for $\ln (\mathrm{REMITPC})$

\begin{tabular}{|c|c|c|c|c|}
\hline \multicolumn{5}{|c|}{$\begin{array}{l}\text { Dependent Variable: LOG(REMITPC) } \\
\text { Method: Least Squares } \\
\text { Date: } 07 / 10 / 09 \text { Time: } 18: 14 \\
\text { Sample (adjusted): } 436 \\
\text { Included observations: } 33 \text { after adjustments }\end{array}$} \\
\hline & Coefficient & Std. Error & t-Statistic & Prob. \\
\hline C & 1.695935 & 0.226963 & 7.472282 & 0.0000 \\
\hline $\mathrm{D}(\mathrm{LOG}(\mathrm{RGDPPC}))$ & 0.210518 & 0.337374 & 0.623990 & 0.5388 \\
\hline $\mathrm{D}(\mathrm{LOG}(\mathrm{R} G N I P C))$ & 3.584994 & 3.398540 & 1.054863 & 0.3024 \\
\hline D(REER) & 0.064324 & 0.130333 & 0.493534 & 0.6263 \\
\hline $\mathrm{D}(\mathrm{CPIM})$ & -0.382674 & 0.147788 & -2.589343 & 0.0164 \\
\hline D(UNRATE) & 0.127891 & 0.175426 & 0.729032 & 0.4733 \\
\hline D(INTERESTDIF) & -0.235761 & 0.101403 & -2.324985 & 0.0293 \\
\hline RESID02(-1) & -0.276619 & 0.750247 & -0.368704 & 0.7157 \\
\hline $\mathrm{D}(\operatorname{LOG}(\mathrm{REMITPC}(-1)))$ & 0.122308 & 0.291067 & 0.420205 & 0.6782 \\
\hline $\mathrm{D}(\mathrm{LOG}(\mathrm{REMITPC}(-2)))$ & 0.494189 & 0.256486 & 1.926772 & 0.0665 \\
\hline R-squared & 0.466831 & \multicolumn{2}{|c|}{ Mean dependent var } & 1.521812 \\
\hline Adjusted R-squared & 0.258200 & \multicolumn{2}{|c|}{ S.D. dependent var } & 1.072231 \\
\hline S.E. of regression & 0.923489 & \multicolumn{2}{|c|}{ Akaike info criterion } & 2.923732 \\
\hline Sum squared resid & 19.61513 & \multicolumn{2}{|c|}{ Schwarz criterion } & 3.377219 \\
\hline Log likelihood & -38.24157 & \multicolumn{2}{|c|}{ Hannan-Quinn criter. } & 3.076316 \\
\hline F-statistic & 2.237591 & \multicolumn{2}{|c|}{ Durbin-Watson stat } & 0.455310 \\
\hline Prob(F-statistic) & 0.057601 & & & \\
\hline
\end{tabular}

The estimation of of the VEC model is given in Table 4 in Appendix. Both Table 4 and Figure 7 show that remittances respond to shocks in real effective exchange rate and interest difference. The impulse response functions (Figure 7) illustrate how remittances react to one standard deviation shocks in Macedonian GDP and German GNI, real effective exchange rate, the price level and the unemployment rate in Macedonia and the difference in short-term interest rates before they are forced back onto their long-term path. 
Figure 7: Cholesky impulse response functions

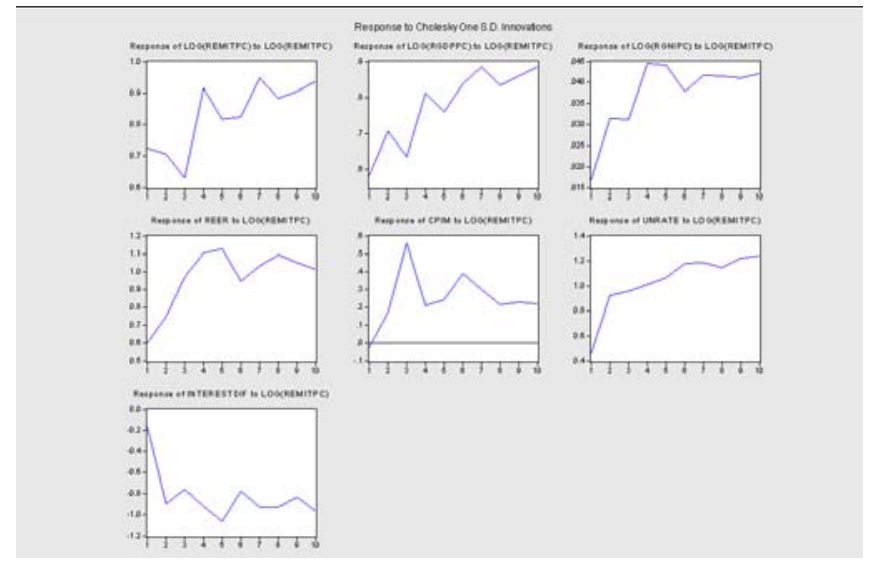

The obtained econometric findings can be summarized as follows:

1. There is a positive significant relationship between remittances sent from Germany to Macedonia and Macedonian real GDP. This relationship proved to be procyclical suggesting that real remittances per capita move in the same direction as the Macedonian real GDP per capita-they would increase when the Macedonia's real GDP would grow, possibly for investment purposes and would drop in times of recessions or economic downturns. Our econometric results suggest that, an increase in Macedonian real GDP per capita by 1 percent leads to an increase in real remittances per capita by 1,08 percent, all else remaining constant. The obtained econometric results are in compliance with the previous econometric research regarding middleincome countries to which Macedonia belongs (Jovicic and Dragutinovic-Mitrovic, 2006) The procyclicality of real remittances to Macedonian real GDP implies that remittances act as a boost to economic activity in times of economic upturns, and as a destabilizing factor to the economy in times of economic downturns with severe negative macroeconomic and microeconomic consequences.

2. Remittances sent from Germany to Macedonia move procyclically with German real output (real GNI): remittances increase during an up cycle in the German economy as a result of the increasing wages of the Macedonian workers and decrease when economic activity in Germany slows down and unemployment rates go up over the business cycle in Germany. In particular, an increase in German real GNI per capita by 1 percent leads to an increase in real remittances per capita by 1,33 percent ceteris paribus. This econometric result is also in line with previous econometric research. According to Sayan and Tekin-Koru (2007), even if remittances move countercyclically with the output in the home countries of migrant workers, the cycles in home and host country economies may concurrently move in the same direction, thereby preventing workers employed in an economy hit by crisis from helping out family members facing similar conditions back home. This is the case with the recent global economic crisis which stroke Germany and Macedonia simultaneously.

3. Remittances fall when the unemployment rate in Macedonia increases: a one percent increase of the Macedonian unemployment rate leads to 0,7 percent reduction in remittances. The sign of the estimated coefficient of unemployment rate in home country is unexpectedly negative, but not significant. This result can be explained with the previous findings that inward remittances coming from Macedonian workers in 
Germany to Macedonia do decrease during period of recessions and economic downturns in Macedonia and in Germany.

4. Remittances increase when the real exchange rate weakens: a one percent depreciation of the denar leads to a 4,45 percent increase in remittances, ceteris paribus. Depreciation of the denar increases remittances due to the fact the Macedonian consumption basket contains a considerable share of imported goods. So in order to preserve the purchasing power of their family members in Macedonia, Macedonian migrant workers in Germany would transfer more money home.

5. Remittances fall when the inflation rate increases: a one percent increase of the inflation rate leads to a 7,98 percent reduction in remittances, assuming that all other variables are constant. Higher inflation rate is a signal of macroeconomic instability and would cause remittance inflows to decline.

6. Remittances fall with the increase of interest rate differential. An increase of the differential between home country and host country treasury bills interest rate by 1 percent, would lead to a decrease in remittances sent from Germany to Macedonia by $3,35 \%$, ceteris paribus. This result is in line with the previous conclusion that higher interest rate differential, as an indicator of higher macroeconomic instability, discourages migrant workers to invest their money in the domestic banks, and it is also in accordance with the relation to the inflation rate.

\section{CONCLUSIONS AND POLICY IMPLICATIONS}

Contrary to the theoretically plausible counter cyclical argument of remittance flows to emerging market economies, our econometric analysis has shown that real remittance inflows from Germany to Macedonia are positively and strongly correlated with Macedonian business cycle, suggesting that they are profit driven and governed by portfolio considerations, and not by altruism or insurance considerations The procyclicality of real remittances to Macedonian real GDP implies that remittances could not cushion large fluctuations in Macedonian output in times of recession or economic downturn. Moreover, the paper finds that real inward remittances receipts move also procyclically with German real output (real GNI).

The variable used to measure the impact of labor market on inward remittances (unemployment rate in home country) had the expected negative sign, but was not significant. Real exchange rate also proved to be an insignificant determinant of the level of per capita real remittances. Depreciation of the denar tends to increase remittances, implying that they may considerably provide insurance against balance of payment deficit since it is statistically significant at $10 \%$ level. The consumer price index is also statistically significant at $1 \%$ level of significance and it indicates that the inflation rate has a considerable negative impact to remittances. As far as the rate of return variable is concerned, results indicate that interest rate differential affected remittances negatively, but not significantly.

These findings have important policy implications. First, due to the procyclical behaviour, remittances can not be a substitute for good economic policies and structural reforms. Second, given the important economic benefits of remittances to Macedonia and the fact that they are far more stable source of external financing unlike FDI, Macedonian government should refocus from motivating the foreign investors to invest in Macedonia though very expensive and ineffective marketing campaigns to maximizing the developmental impact of remittances in Macedonia by offering more investment opportunities to Macedonian migrants, especially to those ones who wish to return to Macedonia. 


\section{REFERENCES}

Dolado, J., Jenkinson, T. and SosvillaRivero, S., (1990), Cointegration and Unit Roots, Journal of Economic Survey, 4, pp 249-273.

Hagen-Zanker, J. and Siegel, M., (2007), The Determinants of Remittances: A Review of the Literature, Maastricht University, Maastricht Graduate School of Governance, p. 7.

Jovicic, M. and Dragutinovic-Mitrovic, R., (2006), Macroeconomic Analysis of Causes and Effects of Remittances: A Panel Model of the SEE countries and a Case Study of Serbia, Paper presented at the GDN Southeast Europe WIIW workshop, May 5-6, 2006.

Ministry of Finance of the Republic of Macedonia, Indicators and Projections, http://www.finance.gov.mk/node/401, Assessed on 10 ${ }^{\text {th }}$ January 2011.

National Bank of the Republic of Macedonia, Statistics, http://www.nbrm.mk/defaulten.asp?ItemID=16C5679A8986CE4391D1F76413410999, Assessed on 10 ${ }^{\text {th }}$ January 2011.

Rapoport, H. and Docquier, F., (2005), The Economics of Migrants' Remittances, IZA Discussion Paper No. 1531, Bonn, March 2005, p. 11-13.

Ratha, D., (2003), Workers' Remittances: An Important and Stable Source of External Development Finance, in Global Development Finance: Striving for Stability in Development Finance, Washington, DC: World Bank, Pp 157-175.

Sayan, S., (2004), Guest Workers' Remittances and Output Fluctuations in Host and Home Countries: The Case of Remittances from Turkish Workers in Germany, Emerging Markets Finance and Trade, Vol. 40(6), Pp 70-84.

Sayan, S., (2006), Business Cycles and Workers' Remittances: How Do Migrant Workers Respond to Cyclical Movements of GDP at Home? IMF Working Papers No. 52, http://www.imf.org/external/pubs/ft/wp/w006/wp0652, Assessed on 20 ${ }^{\text {th }}$ January 2011.

Sayan, S. and Tekin-Koru, A., (2007), Remittances, Business Cycles and Poverty: The Recent Turkish Experience, MPRA Paper 6029.

Sayan, S. and Tekin-Koru, A., (2007), Business Cycles and Remittances: A Comparison of the Cases of Turkish Workers in Germany and Mexican Workers in the US, MPRA Paper No. 6030.

Sayan, S. and Tekin-Koru, A., (2008), The Effects of Economic Development and Policies in Host Countries on Workers' Remittances Receipts of Developing Countries: The Cases of Turkey and Mexico Compared” in Lucas et al (ed.), The Impact of Rich Country Policies on Developing Economies, London: Edward Elgar.

State Statistical Office of the Republic of Macedonia, Statistical Yearbooks for 2000-2010.

State Statistical Office of the Republic of Macedonia, Statistics, http://www.stat.gov.mk/SoopstenijaPoOblasti_en.aspx, Assessed on 10 ${ }^{\text {th }}$ January 2011.

The World Bank, (2006), Economic implications of remittances and migration, Global economic prospects, No. 34320.

The World Bank, (2011), Migration and Remittances Factbook 2011

The World Bank, http://data.worldbank.org/indicator, Assessed on 11 ${ }^{\text {th }}$ January 2011.

The World Bank, http://data.worldbank.org/data-catalog/migration-and-remittances, Assessed on $11^{\text {th }}$ January 2011. 


\section{APPENDIX}

Table 4: Vector error correction estimates

\begin{tabular}{|c|c|c|c|c|c|c|c|}
\hline \multicolumn{5}{|c|}{ Vector Error Correction Estimates } & & & \\
\hline \multicolumn{8}{|c|}{ Date: 07/10/09 Time: 15:43 } \\
\hline \multicolumn{8}{|c|}{ Sample (adjusted): 436} \\
\hline \multicolumn{8}{|c|}{ Included observations: 33 after adjustments } \\
\hline \multicolumn{8}{|c|}{ Standard errors in ( ) \& t-statistics in [ ] } \\
\hline & & & & & & & \\
\hline \multirow[t]{2}{*}{ Cointegrating Eq: } & CointEq1 & & & & & & \\
\hline & & & & & & & \\
\hline \multirow{4}{*}{$\begin{array}{l}\text { LOG } \\
\text { (REMITPC(-1)) } \\
\text { LOG } \\
\text { (RGDPPC(-1)) }\end{array}$} & 1.000000 & & & & & & \\
\hline & 2.307812 & & & & & & \\
\hline & $(0.23271)$ & & & & & & \\
\hline & [ 9.91704] & & & & & & \\
\hline \multirow{3}{*}{$\begin{array}{l}\text { LOG } \\
(\text { RGNIPC }(-1))\end{array}$} & 15.72516 & & & & & & \\
\hline & $(2.50051)$ & & & & & & \\
\hline & [ 6.28877] & & & & & & \\
\hline \multirow[t]{3}{*}{ REER(-1) } & -0.621153 & & & & & & \\
\hline & $(0.04028)$ & & & & & & \\
\hline & {$[-15.4203]$} & & & & & & \\
\hline \multirow{3}{*}{ CPIM(-1) } & -0.874719 & & & & & & \\
\hline & $(0.08455)$ & & & & & & \\
\hline & {$[-10.3458]$} & & & & & & \\
\hline \multirow[t]{3}{*}{ UNRATE(-1) } & -1.996525 & & & & & & \\
\hline & $(0.16846)$ & & & & & & \\
\hline & [-11.8519] & & & & & & \\
\hline \multirow{3}{*}{ INTERESTDIF(-1) } & 0.307529 & & & & & & \\
\hline & $(0.04893)$ & & & & & & \\
\hline & [6.28466] & & & & & & \\
\hline $\mathrm{C}$ & 61.68588 & & & & & & \\
\hline Error Correction: & $\begin{array}{l}\text { D(LOG(RE } \\
\text { MITPC)) }\end{array}$ & $\begin{array}{l}\text { D(LOG(R } \\
\text { GDPPC)) }\end{array}$ & $\begin{array}{l}\text { D(LOG(R } \\
\text { GNIPC)) }\end{array}$ & D(REER) & D(CPIM) & $\begin{array}{l}\text { D(UNRA } \\
\text { TE) }\end{array}$ & $\begin{array}{l}\text { D(INTER } \\
\text { ESTDIF) }\end{array}$ \\
\hline \multirow[t]{3}{*}{ CointEq1 } & 0.044679 & -0.026848 & 0.005414 & 0.579551 & 0.005577 & 0.186553 & -0.626185 \\
\hline & $(0.09865)$ & $(0.08446)$ & $(0.00602)$ & $(0.15982)$ & $(0.16271)$ & $(0.14528)$ & $(0.17375)$ \\
\hline & [0.45292] & {$[-0.31788]$} & [0.89869] & [3.62635] & {$[0.03427]$} & [ 1.28412$]$ & {$[-3.60396]$} \\
\hline \multirow{3}{*}{$\begin{array}{l}\text { D(LOG } \\
(\text { REMITPC(-1))) }\end{array}$} & 0.288026 & 0.752692 & 0.001573 & -0.612655 & -0.786767 & 0.261382 & -0.706977 \\
\hline & $(0.53977)$ & $(0.46215)$ & $(0.03296)$ & $(0.87448)$ & $(0.89031)$ & $(0.79492)$ & $(0.95071)$ \\
\hline & [0.53361] & [ 1.62867$]$ & {$[0.04771]$} & {$[-0.70059]$} & {$[-0.88370]$} & [0.32882] & {$[-0.74363]$} \\
\hline \multirow{3}{*}{$\begin{array}{l}\mathrm{D}(\mathrm{LOG} \\
(\mathrm{REMITPC}(-2)))\end{array}$} & -0.258248 & -0.180438 & 0.000401 & -0.098818 & 0.197116 & 0.083792 & 1.729883 \\
\hline & $(0.60189)$ & $(0.51533)$ & $(0.03676)$ & $(0.97511)$ & $(0.99275)$ & $(0.88639)$ & $(1.06011)$ \\
\hline & {$[-0.42907]$} & {$[-0.35014]$} & [0.01091] & {$[-0.10134]$} & [ 0.19855$]$ & [ 0.09453] & [1.63179] \\
\hline $\begin{array}{l}\mathrm{D}(\mathrm{LOG} \\
(\mathrm{RGDPPC}(-1)))\end{array}$ & -0.329921 & -0.413030 & -0.022419 & -0.568755 & 1.333526 & 0.273779 & 1.469170 \\
\hline
\end{tabular}




\begin{tabular}{|c|c|c|c|c|c|c|c|}
\hline & $(0.65484)$ & $(0.56067)$ & (0.03999) & (1.06089) & (1.08009) & $(0.96437)$ & (1.15338) \\
\hline & {$[-0.50382]$} & {$[-0.73667]$} & {$[-0.56061]$} & {$[-0.53611]$} & [ 1.23464] & [0.28389] & [1.27380] \\
\hline \multirow{3}{*}{$\begin{array}{l}\text { D(LOG } \\
(\text { RGDPPC(-2))) }\end{array}$} & 0.257962 & 0.395720 & -0.014930 & -0.194529 & 0.101964 & -0.028746 & -0.614903 \\
\hline & $(0.68726)$ & $(0.58843)$ & $(0.04197)$ & $(1.11341)$ & $(1.13357)$ & $(1.01212)$ & $(1.21048)$ \\
\hline & {$[0.37535]$} & {$[0.67251]$} & {$[-0.35573]$} & {$[-0.17471]$} & {$[0.08995]$} & {$[-0.02840]$} & {$[-0.50798]$} \\
\hline \multirow{3}{*}{$\begin{array}{l}\mathrm{D}(\mathrm{LOG} \\
(\mathrm{RGNIPC}(-1)))\end{array}$} & -9.792375 & -5.788950 & -0.025403 & -5.409892 & 2.077943 & -4.658595 & 27.95346 \\
\hline & $(4.48805)$ & (3.84265) & $(0.27409)$ & (7.27101) & $(7.40262)$ & $\begin{array}{l}(6.60950) \\
\end{array}$ & (7.90489) \\
\hline & {$[-2.18188]$} & {$[-1.50650]$} & {$[-0.09268]$} & {$[-0.74404]$} & {$[0.28070]$} & {$[-0.70483]$} & [3.53622] \\
\hline \multirow{3}{*}{$\begin{array}{l}\mathrm{D}(\mathrm{LOG} \\
(\mathrm{RGNIPC}(-2)))\end{array}$} & -0.537057 & 3.487960 & -0.473854 & -1.940851 & 5.478032 & 4.838455 & 12.26524 \\
\hline & (3.83386) & (3.28253) & $(0.23413)$ & (6.21117) & $(6.32360)$ & (5.64609) & (6.75266) \\
\hline & {$[-0.14008]$} & {$[1.06258]$} & {$[-2.02386]$} & {$[-0.31248]$} & {$[0.86628]$} & {$[0.85696]$} & [1.81636] \\
\hline \multirow{3}{*}{ D(REER(-1)) } & 0.134106 & 0.033100 & 0.015000 & -0.060398 & 0.017551 & 0.204712 & -0.510940 \\
\hline & $(0.11321)$ & $(0.09693)$ & $(0.00691)$ & $(0.18341)$ & $(0.18673)$ & $(0.16672)$ & $(0.19940)$ \\
\hline & [ 1.18458$]$ & [ 0.34148] & [ 2.16962] & {$[-0.32931]$} & [ 0.09399] & [ 1.22786$]$ & {$[-2.56240]$} \\
\hline \multirow{3}{*}{\begin{tabular}{|l} 
D(REER(-2)) \\
\end{tabular}} & 0.194521 & 0.115109 & -0.003765 & -0.352467 & 0.152173 & 0.059083 & -0.732115 \\
\hline & $(0.13513)$ & $(0.11570)$ & $(0.00825)$ & $(0.21893)$ & $(0.22289)$ & $(0.19901)$ & $(0.23801)$ \\
\hline & [ 1.43946] & [ 0.99488] & {$[-0.45622]$} & {$[-1.60996]$} & [ 0.68272] & [ 0.29688$]$ & {$[-3.07592]$} \\
\hline \multirow[t]{3}{*}{$\mathrm{D}(\mathrm{CPIM}(-1))$} & 0.030090 & 0.053242 & 0.005657 & 0.067124 & 0.158748 & -0.139902 & -0.010392 \\
\hline & $(0.15432)$ & $(0.13213)$ & $(0.00942)$ & $(0.25002)$ & $(0.25454)$ & $(0.22727)$ & $(0.27182)$ \\
\hline & [ 0.19498] & [ 0.40294] & [ [0.60023] & {$[0.26848]$} & [ 0.62366$]$ & {$[-0.61557]$} & {$[-0.03823]$} \\
\hline \multirow[t]{3}{*}{ D(CPIM(-2)) } & -0.057157 & -0.150737 & 0.005940 & 0.591865 & -0.010400 & -0.259231 & 0.087397 \\
\hline & $(0.13330)$ & $(0.11413)$ & $(0.00814)$ & $(0.21596)$ & $(0.21987)$ & $(0.19631)$ & $(0.23478)$ \\
\hline & {$[-0.42878]$} & {$[-1.32074]$} & [0.72970] & [ 2.74066] & {$[-0.04730]$} & {$[-1.32052]$} & {$[0.37224]$} \\
\hline \multirow[t]{3}{*}{ D(UNRATE(-1)) } & 0.078268 & -0.117764 & 0.028395 & 0.977678 & -0.226927 & -0.193752 & -1.214013 \\
\hline & $(0.20361)$ & $(0.17433)$ & $(0.01243)$ & $(0.32987)$ & $(0.33584)$ & $(0.29986)$ & $(0.35863)$ \\
\hline & [0.38439] & {$[-0.67551]$} & [2.28355] & [2.96380] & {$[-0.67569]$} & {$[-0.64614]$} & {$[-3.38513]$} \\
\hline \multirow[t]{3}{*}{ D(UNRATE(-2)) } & 0.229066 & -0.074764 & 0.010281 & 0.425900 & -0.689128 & 0.217203 & -0.432186 \\
\hline & $(0.17443)$ & $(0.14935)$ & $(0.01065)$ & $(0.28259)$ & $(0.28771)$ & $(0.25688)$ & $(0.30723)$ \\
\hline & [1.31322] & {$[-0.50061]$} & [ 0.96510] & [ 1.50712] & {$[-2.39525]$} & {$[0.84554]$} & {$[-1.40673]$} \\
\hline \multirow{3}{*}{$\begin{array}{l}\text { D(INTERESTDIF } \\
(-1))\end{array}$} & 0.203990 & 0.132319 & 0.003395 & -0.078784 & -0.283233 & 0.198798 & 0.266145 \\
\hline & $(0.11249)$ & $(0.09631)$ & $(0.00687)$ & $(0.18224)$ & $(0.18554)$ & $(0.16566)$ & $(0.19813)$ \\
\hline & [ 1.81345] & $\begin{array}{l}{[1.37387]} \\
\end{array}$ & [ 0.49415] & {$[-0.43231]$} & {$[-1.52656]$} & [1.20005] & {$[1.34331]$} \\
\hline \multirow{3}{*}{$\begin{array}{l}\text { D(INTERESTDIF } \\
(-2))\end{array}$} & -0.117175 & -0.119552 & -0.015931 & -0.242424 & 0.162403 & -0.106950 & 0.228282 \\
\hline & $(0.08856)$ & $(0.07582)$ & $(0.00541)$ & $(0.14347)$ & $(0.14607)$ & $(0.13042)$ & $(0.15598)$ \\
\hline & {$[-1.32314]$} & {$[-1.57672]$} & {$[-2.94571]$} & {$[-1.68970]$} & [1.11183] & {$[-0.82005]$} & [1.46354] \\
\hline \multirow[t]{3}{*}{$\mathrm{C}$} & 0.458025 & 0.224285 & 0.026450 & -1.113403 & 0.512902 & 0.437733 & -1.622762 \\
\hline & $(0.30840)$ & $(0.26405)$ & $(0.01883)$ & $(0.49964)$ & $(0.50868)$ & $(0.45418)$ & $(0.54320)$ \\
\hline & [1.48515] & [0.84939] & [1.40436] & {$[-2.22842]$} & [1.00830] & {$[0.96378]$} & {$[-2.98743]$} \\
\hline & & & & & & & \\
\hline
\end{tabular}




\begin{tabular}{|c|c|c|c|c|c|c|c|}
\hline "R-squared & 0.439896 & 0.386452 & 0.609321 & 0.622711 & 0.514838 & 0.513515 & 0.763211 \\
\hline Adj. R-squared & -0.054313 & -0.154914 & 0.264605 & 0.289809 & 0.086753 & 0.084264 & 0.554279 \\
\hline Sum sq. resids & 8.963118 & 6.570598 & 0.033428 & 23.52521 & 24.38455 & 19.43934 & 27.80582 \\
\hline S.E. equation & 0.726114 & 0.621696 & 0.044344 & 1.176366 & 1.197658 & 1.069341 & 1.278920 \\
\hline F-statistic & 0.890102 & 0.713846 & 1.767600 & 1.870555 & 1.202655 & 1.196305 & 3.652920 \\
\hline Log likelihood & -25.31905 & -20.19558 & 66.94020 & -41.24080 & -41.83277 & -38.09303 & -43.99915 \\
\hline Akaike AIC & 2.504185 & 2.193671 & -3.087285 & 3.469139 & 3.505016 & 3.278365 & 3.636312 \\
\hline Schwarz SC & 3.229764 & 2.919251 & -2.361705 & 4.194719 & 4.230596 & 4.003945 & 4.361891 \\
\hline Mean dependent & 0.034061 & 0.039212 & 0.018197 & -0.566667 & 0.657576 & 0.039394 & -0.036364 \\
\hline S.D. dependent & 0.707164 & 0.578500 & 0.051710 & 1.395902 & 1.253253 & 1.117458 & 1.915631 \\
\hline \multicolumn{2}{|c|}{$\begin{array}{l}\text { Determinant resid covariance } \\
\text { (dof adj.) }\end{array}$} & $1.40 \mathrm{E}-06$ & & & & & \\
\hline \multicolumn{2}{|c|}{ Determinant resid covariance } & $1.35 \mathrm{E}-08$ & & & & & \\
\hline \multicolumn{2}{|l|}{ Log likelihood } & -28.78102 & & & & & \\
\hline \multicolumn{2}{|c|}{ Akaike information criterion } & 8.956426 & & & & & \\
\hline \multicolumn{2}{|l|}{ Schwarz criterion } & 14.35292 & & & & & \\
\hline
\end{tabular}

\title{
ULOGA NOVČANIH POŠILJAKA U FINANCIJSKOJ KRIZI: EMPIRIJSKI DOKAZI IZ MAKEDONIJE
}

\begin{abstract}
SAŽETAK
Nedavna globalna financijska kriza je ugrijala raspravu među ekonomistima u vezi uloge inozemnig doznaka radnika u vrijeme financijske krize: Jesu li oni amortizer ili odašiljač šoka? Cilj ovog rada je utvrditi da li doznake poslane u Makedoniju imaju stabilizirajući ili destabilizirajući učinak. Određivanjem vektorskog modela s korekcijom odstupanja (VEC), nalazimo dokaze da realne doznake imaju destabilizirajući učinak na ekonomije obe zemlje: zemlja porekla (Makedonija) i zemlja krajnjeg odredišta (Njemačka). Stoga, ni ne mogu ublažiti velike fluktuacije u makedonske proizvodnje u fazi gospodarske krize.
\end{abstract}

Ključne riječi: doznake, migracija, cikličnost, financijska kriza, vektorski model s korekcijom odstupanja (VEC)

JEL klasifikacija: C22, F29, J61, O11, O24 